\title{
Toledo Koleksiyonu: Sebepleri ve Sonuçlarıyla İlk Oryantalist Çalışmalar
}

\section{Tuğba ÖZTüRK*}

Toledo Collection:

The First Orientalist Studies with their Reasons and Results

Citation/@: Öztürk, Tuğba, (2015). Toledo Collection: The First Orientalist Studies with their Reasons and Results, Milel ve Nihal, 12 (1), 55-80.

Abstract: Before Muslim sovereignty, Toledo had already so ethnically, religiously and culturally diverse structure. Its fame was crowned when it hosted the first translations from Arabic into Latin. It has known as Toledo Collection and it has firstly consisted of many translations such as Mathematics, Astronomy, Medicine, and later by influencing of the Crusades and ahead the Holy Qur'an was also translated. Besides that, some widespread religious and ritualistic texts among people were translated into Latin in pioneering of Peter the Venerable. Therefore, these activities had changed perception of Islam and Muslims in the West as well as had started to have written down polemical texts against Islam by taking advantage of these translations. Because of that, it's possible to describe these studies as first orientalist studies. The Muslim intellectual accumulation in the ninth century was the first wave of enlightenment which had started the renaissance in 12th century in the West. Our paper deals with Toledo Collection in the context of analyzing translators, the translated books and examines the results both for the East and the West alike.

Key Words: Toledo Collection, Peter the Venerable, orientalist studies, first translations.

\footnotetext{
* Arş .Gör., Ankara Üniversitesi, İlahiyat Fakültesi, Kelam Anabilim Dalı [ozturkt@ankara.edu.tr]
} 
Atıf/@: Öztürk, Tuğba, (2015). Toledo Koleksiyonu: Sebepleri ve Sonuçlarıyla İlk Oryantalist Çalışmalar, Milel ve Nihal, 12 (1), 55-80.

Öz: Toledo, Müslümanların hâkimiyeti altına girmeden önce de sonra da çok etnik kökenli, çok dinli ve çok kültürlü bir yapıya sahip olmuştur. Toledo'nun bu şöhreti, Arapça'dan Latince'ye yapılan ilk çevirilere ev sahipliği yapmış olmasıyla taçlanmıştır. Tarihe "Toledo Koleksiyonu" olarak geçen çalışmanın ilk zamanlarında Tıp, Astronomi, Geometri, Matematik gibi alanlarda tercümeler yapılmış; daha sonra Haçlı Seferlerinin de etkisiyle başta Kur'an olmak üzere Peter the Venerable'ın öncülüğünde halk arasında yaygın olan dini metinlerin bir kısmının Latince'ye çevirisi gerçekleştirilmiştir. Böylece hem Batı'da var olan İslam algısında farklılaşma sağlanmış hem de bu tercüme metinlerden yararlanılarak İslam'a karşı reddiyeler/polemikler yazılmaya başlanmıştır. Bu kapsamlı etkisinden dolayı, çevirilerin ilk oryantalist çalışmalar olarak tanımlanması mümkündür. Müslümanların meydana getirdikleri entelektüel birikimle IX. yüzyılda yarattıkları Rönesans, Toledo Koleksiyonundaki çeviriler sonucunda Batı'da XII. yüzyılda ilk Rönesans olarak adlandırılan uyanışı tetiklemiştir. Çalışmamız Toledo koleksiyonunu çevirmenleri ve tercüme edilen kitapları bağlamında ele almakta ve Doğuda ve Batıdaki sonuçlarıyla incelemektedir.

Anahtar Kelimeler: Toledo Koleksiyonu, Peter the Venerable, polemikler, oryantalist çalışmalar, ilk tercümeler.

Ger Endülüs olmasa ziyâdâr,

Kim Avrupa'yı ederdi bidâr. ${ }^{1}$

\section{Giriş: Tarihsel ve Kültürel Dokusuyla Toledo}

Müslümanlar için Toledo'nun tarihi miladi 712 yılında Tarık b. Ziyad'ın fethiyle başlamaktadır. Onun öncesinde Toledo Vizigot yönetiminin başkenti ve önemli bir kültür merkeziydi. Emevi hâkimiyetinin altında olduğu zamanlarda ise merkezi yönetime şeklen bağlıydı. Bu dönemde nüfus yapısı Hıristiyanlar, yani yerli halk, küçük bir azınlık halinde olan Yahudiler ve az sayıda Arap ve Berberilerden oluşmaktayd1. ${ }^{2}$ Müslümanların verdikleri taahhütler neticesinde Toledo yine Vizigotlar döneminde olduğu gibi İspanya

\footnotetext{
1 “Eğer Endülüs 1şık saçmasaydı, Avrupa'yı bilgisizlik uykusundan kim uyand1rırdı?" Ziya Paşa, Endülüs Tarihi, Ziya Paşa, Sesli Kitaplar, İstanbul, 2004.

2 Mehmet Özdemir, "İslam Tarihinde Doğululaşma ve Batılılaşma Tartışmaları Tuleytula Örneği", İslamiyat, sayı 3, 2004, s. 15. (Bkz. Reinhart Dozy, Histoire des Musulmanes d'Espagne, Leiden, 1861, c. II, s. 63).
} 
Toledo Koleksiyonu: Sebepleri ve Sonuçlarıyla İlk Oryantalist Çalışmalar için başpiskoposluk merkezi olma özelliğini devam ettirmiştir. ${ }^{3} \mathrm{Vi}$ zigot'lar döneminde başkentlik yapan Toledo öteden beri Hıristiyan konsillere ev sahipliği yapma geleneğine sahipti. Müslümanlar Toledo'yu fethettiğinde önceleri Araplaştırma politikası izlemediği için yerli halk, kimliğini kendi kültür kodları içerisinde koruyabilmiştir. X. yüzyıla gelindiğinde ise Toledo coğrafi olarak genişlemiş, nüfusu da artmıştır. Bu yapısıyla Toledo, Endülüs'ün Kurtuba'dan sonraki ikinci büyük şehri olma özelliğine sahip olmuştur. ${ }^{4}$

Toledo bu tarihsel süreçte eğitim dilinin Arapça olması, halkın Doğu'ya gidip ilim tahsil etmeye olan merakı ve Arap şiirlerine olan ilgisi dolayısıyla Arapça sadece Müvelledler ${ }^{5}$ arasında değil, aynı zamanda Müsta' ribler ${ }^{6}$ arasında da konuşulabilen geniş bir yayılma alanına sahip olmuştur. Böylece Araplaşma (arabization) faaliyeti pratik ve kültürel bir bağlam içerisinde başlamıştır. Yine bu dönemde Hıristiyan-Müslüman-Yahudiler arası ilişkiler tüm dünyaya örnek olacak düzeyde birlikte yaşama tecrübesini ortaya çıkarmıştır. ${ }^{7}$ Bu birlikte yaşam tecrübesi convivencia adıyla Batı literatüründe yerini almıştır.

Tarihler 1085'i gösterdiğinde Avrupalıların reconquista olarak adlandırdıkları, toprakları yeniden ele geçirme hareketi içerisinde Toledo8, Müslümanların egemenliğinden çıkıp Hıristiyan Kastilya Krallığının hâkimiyetine girmiştir. Bu politik kırılma Toledo'da yaşayan Endülüs bakiyesi Müslüman halk üzerinde Batılılaştırma (occidentalization) çalışmalarının önünü açmıştır.

3 Özdemir, “İslam Tarihinde Doğululaşma ve Batılılaşma Tartışmaları Tuleytula Örneği", İslamiyat,s. 16. (Bkz. Isidoro de las Cagigas, Los Mozarabes, Madrid 1947, c. I, s. 149).

4 Özdemir, "İslam Tarihinde Doğululaşma ve Batılılaşma Tartışmaları Tuleytula Örneği", İslamiyat,s.16.

5 Müvelled: Batı'da İslamiyeti kabul eden ilk İspanyolların çocukları hakkında kullanılmıştır. (Bkz. Rahmi Er, “Müvelledun” maddesi, DİA, c. 32, İstanbul, 2006, s. 228).

6 Müsta' rib: İslam hâkimiyeti altında kalıp Araplaşan Endülüs Hıristiyanlarına verilen addır. (Bkz. Jorge Lirola, "Müsta' rib" maddesi, DİA, c.32, İstanbul, 2006, s. 123).

7 Özdemir, “İslam Tarihinde Doğululaşma ve Batılılaşma Tartışmaları Tuleytula Örneği", İslamiyat, s.18.

8 Jean-Marie Gaudeul, Encounters\&Clashes Islam and Chrsitianity in History, Pontificio Istituto di Studi Arabi e Islamici, Roma, 1990, s.164. 
XII ve XIII. yüzyıllara gelindiğinde Toledo Müslüman, Yahudi, müsta'rib ve diğer azınlıklardan oluşan çoğulcu toplum yapısına hâkim olmuştur. Karşılıklı etkileşim sonucu olarak Endülüs'te bilimsel ve kültürel gelişmeler yaşanmıştır. Ayrıca şehirde İslami eserler ihtiva eden kütüphanelerin bulunması da Toledo'yu Avrupa'daki araştırmacılar için cazibe merkezi haline getirmiştir. Söz konusu yüzyıllarda bilimin Toledo'da olduğu kanaati yaygınlaşmış ve burası artık Arap biliminin elde edilebileceği önemli bir merkez olarak görülmeye başlanmıştır. Nitekim yapılan bilimsel çalı̧̧malar Toledo'nun Arap biliminden tercümeler aracılı̆̆ıyla maksimum düzeyde yararlanma imkânı sağladığını göstermiştir. ${ }^{9}$ İlk etapta tıp, matematik, astronomi, geometri gibi alanlarda yapılan tercümelere zamanla İslam'a karşı reddiye hazırlayabilmek amacıyla İslami eserlerin tercümesi eklenip oryantalistik bir çalışmaya çevrilmiştir. Sonuçta oluşan külliyat ise tarihte Toledo Koleksiyonu olarak yerini almıştır. Şimdi Toledo Koleksiyonu hakkında daha detaylı bir inceleme yapalım.

\section{1-Tercüme Hareketinin Başlamasının Temel Amacı ve Mantığı}

\section{1.a-Matematik, Astronomi ve Tıbba Dair Bilgi Elde Etme Çabası}

İspanya' da Hıristiyanlar Müslümanlarla karşılaştıklarında, Hıristiyanlarda iki tür refleks ortaya çıkmıştır. İlki Müslümanların gücü karşısında hissettikleri zafiyet ve bunun doğurduğu korku; ikincisi ise Avrupalıların Müslümanlara karşı üstünlük iddialarına rağmen, müslümanlardan bilimsel olarak geride bulundukları gerçeğinden beslenen bir hayranlık duygusuydu. Ancak reconquista hareketinin getirdiği bir cesaretle Hıristiyanlar korkuların yenmeye ve hayranlık duydukları Müslüman kültürüyle ilgilenip bilgi edinmeye başlamışlardır. ${ }^{10}$

Arapçadan Latinceye ilk tercümeler IX. yüzyılda Matematik ve Astronomi alanlarında başladığı iddia edilmektedir. Bu biraz zayıf bir rivayet olmasının yanında Hristiyan tercümanlardan Aurillaclı Gerbert'in ${ }^{11}$ (ö.1003) Kurtuba'ya gidip yasak olmasına rağmen Astronomi ve Matematik'e dair eğitim aldığı bilinmektedir. Böylece matematik ve astronomi alanlarında zamanındaki birçok Hıristiyan 
Toledo Koleksiyonu: Sebepleri ve Sonuçlarıyla İlk Oryantalist Çalışmalar bilginden daha ileri bir seviyeye gelmiş ve içinde Arapça eserlerin tercümelerinin bulunduğu kendine ait zengin bir kütüphane oluşturmuştur. Gerbert'in önemi "matematik için hazırladığ1 cetvellerinde Arapça rakamların kullanıldığı ilk vesika olması"nda yatmaktadır. Ama bu rakamların Avrupa'da kullanımı için bir süre daha geçmesi gerekmiştir. ${ }^{12}$ Astronomi ve Matematikle ilgili eserlerin tercümesinden sonra Tıbba geçilmiş ve ilk olarak Afrikalı Konstantin Arapçadan Latinceye tercümeyi gerçekleştirmiştir. ${ }^{13}$ Daha sonra tercüme çalışmaları Raymond de Sauvetât (ö.1187) tarafından sürdürülmüştür ve 1125-1151 yılları arasında söz konusu çalışmalar daha sistematik bir çerçeveye kavuşmuştur. Raymond'un çalışma ekibinde yer alan Cremonalı Gerard Toledo'ya gelip 1187'deki ölümüne kadar tercümelere katkı yapmayı sürdürmüştür. ${ }^{14}$

\section{1.b-İslam’a İlişkin Bir Algı Geliştirme Çabası/ İlk Oryantalistik ${ }^{15}$ Faaliyetler}

Tercüme faaliyetlerinin başladığı dönemde Hıristiyanlar İslamiyeti ilahi değil, putperest bir din olarak görüyorlardı. Aynı dönemde Haçlı seferlerinin gerçekleşmesi ve Müslümanlarla Hıristiyanlar arasında sadece dinî değil aynı zamanda iktidar mücadelesinin de olması sebebiyle genel anlamda İslamiyet, özelde ise Hz. Muhammed çeşitli suçlamalara maruz kalmıştır. Bunlardan bazıları; Muhammed isminin karanlıklar prensi Mahound'a dönüştürülmesi, Müslümanları Sarasenler16/Hagarenler ${ }^{17}$ olarak adlandırıp onların

\footnotetext{
Watt, İslam Avrupa'da, s. 121.

Watt, İslam Avrupa'da, s. 122.

Watt, İslam Avrupa'da, s.124.

5 Oryantalizm kelimesi 18. Yüzyılda Fransızca "orientaliste" kelimesinden yola ç1karak kullanılmaya başlanmış olmasına rağmen, biz söz konusu tarihlerde de yapılan işin aynı olması sebebiyle bu terimi kullanmaktayız. Oryantalizm kelimesi için; bkz. Robert Irwin, Oryantalistler ve Düşmanları, çev. Bahar Tırnakçı, İstanbul, 2008, s.11.

16 Sarazen/Saracan: Araplara ve Müslümanlara özellikle Latin Hıristiyanları tarafından verilen bir isimdi. Apollo, Mars, Pluto, Alkaron (Kur'an sözcüğünden türetilmiş) gibi putlara ve şeytanlara tapanlar anlamında kullanılmaktaydı. Ayrıntılı bilgi için bkz: John Victor Tolan, Saracens: Islam in The Medivial Europien Imagination, Columbia University Press, 2002; Aziz al-Azmeh, İslamlar ve Moderniteler, çev. Elçin Gen, İstanbul, 2014, s.253.

17 Sarazen veya Hagaren iki şekilde de kullanılmıştır. Ayrıntılı bilgi için bkz; Irwin, Oryantalistler ve Düşmanları, s. 26.
} 
Hz. Muhammed'e taptığını iddia etmeleridir. Hatta zamanın halifesinin de bir anlamda papa gibi Hz. Muhammed'in yeryüzündeki vekili olarak kabul edildiği ve Kubbetu's-Sahra'da (Templum Domini) ve diğer büyük camilerde ona ibadet edildiği yönünde Hiristiyan halk üzerinde algı oluşturma çabalarında başarılı olunmuştur. ${ }^{18}$

Bilindiği gibi İslamiyete karşı bu görüşler ve suçlamalar, ilk defa Yuhanna ed-Dımeşkı (Yahya ed-Dımeşki, Yuhanna İbn Mansur, Şamlı Aziz İoannes) olarak bilinen bir Hıristiyan papaz tarafından gündeme getirilmiştir. Yuhanna'nın 742 yılından sonra yazdığ 1 Bilgi Pınarı adlı eserinde Müslümanlar Ariusçu ve heretik bir şema içerisinde mütalaa edilmiştir. Esere göre Hz. Muhammed Ariusçu bir keşişten eğitim almış, bu yüzden Oğul ile Baba'nın ortak sonsuzluğunu kabul etmemektedir. Ayrıca Hz. Peygambere vahyolunanın büyük bölümünün ise Eski ve Yeni Ahit'ten çalındığı iddia edilmektedir. Hiristiyanlar tercüme faaliyetleri sırasında bu eserin $\mathrm{Yu}-$ nanca'dan Latince'ye tercüme edildiğini söylemektedirler. ${ }^{19} \mathrm{Bu}$ anlayış Doğu ve Batı Hıristiyanları arasında düşünülmeden benimsenmiş ve Müslümanların putperest olduğu inancı kabul ettirilmiştir. Bu algıyı güçlendirmek için papanın vaazlarının yanında çeşitli kitaplar ve şiirler de yazılmıştır. Dolayısıyla Haçlı seferlerine katılan askerler de putperestleri öldürmek için yola çıkmış kişilerden oluşturulmuştu. Amaçları da Hıristiyanlıktan dönüp zındık olanları veya kâfirleri öldürmekti. ${ }^{20}$

Haçlı seferlerinde İslamiyet'le ilgili böyle bir algı belirleyici olmuş ve Müslümanlarla savaşlar yapılmıştır. Fakat Hıristiyanlardan bazıları Müslümanlara savaşla değil ilimle karşı konulabileceği düşüncesini savunmuşlardır. İşte Hıristiyanların bu düşüncesi sebebiyle biz ilk oryantalistik faaliyetin burada gerçekleştiği kanaatini taşımaktayız. İlimle karşı konulması gerektiğini savunanlar arasında Kluni rahiplerinin ve kilise babalarının önemli isimlerinden olan kutsal Peter olarak vasıflandırdıkları Peter the Venerable vardı. Bu sebeple Toledo Koleksiyonu ve yaptığı tercümeler onun için ayrı bir öneme sahipti. Savaşarak Müslümanları Hıristiyanlaştırılmanın

18 Şaban Ali Düzgün, "Bir Şiddetin Anatomisi: Müslüman ve Latin Batı Dünyası Arasında Haçlı Seferleri Dönemindeki İlişkiler", Dini Araştırmalar, sayı: 20, 2007, s. 73-92; Al-Azmeh, İslamlar ve Moderniteler, s. 253.

19 Robert Irwin, Oryantalistler ve Düşmanlarl, s. 28-29.

20 Düzgün, "Bir Şiddetin Anatomisi", Dini Araştırmalar, s. 73-92. 

yanlış olduğunu, bunun ancak ilimle gerçekleşebileceğini savunmuştur. Ancak burada şu soru sorulabilir; Kur'an'ı Latinceye tercüme etmek yerine İncil'i Arapçaya tercüme etmek bunun için daha kestirme bir yol olmaz mıdı? Bunun cevabı ise o zamanki Hıristiyan halkın seviyesini göstermektedir. Zira o dönemde ve o topraklarda yaşayan Hıristiyanlar kendi dilleri olan Latinceden başkasını bilmiyorlardı. Dolayısıyla Müslümanlarla iletişime geçmeden önce Hıristiyanların bu dinle alakalı olarak kendilerini geliştirmeleri gerekiyordu. Bu da ancak kendi dillerine yapılan tercümeyle gerçekleşebilirdi. ${ }^{21}$

\section{2-Toledo Koleksiyonu ve Misyonu}

Bir olayı doğru tahlil edebilmek için onun ortaya çıkmasını sağlayan faktörleri dikkatli incelemek gerekmektedir. Toledo koleksiyonunun ortaya çıkmasının arkasında da çeşitli sebepler yatmaktadır. Bunu açıklamaya başlamak için; aslında Paris'te kutsal bir papaz olarak bilinen Pierre Maurice de Montboissier'in ${ }^{22}$ (Peter the Venerable) Endülüs'e niye gittiği, böyle bir projeyi niçin başlattığı sorularını sormak gerekir. Acaba bu proje daha önceki bir çalışmanın devamı veya şerhi şeklinde olabilir mi?

Afrikalı Konstantin ile Endülüs'te başlayan Arapçadan Latinceye tercüme faaliyeti Peter the Venerable'ın kurduğu okulla sistemleşmiştir. Konstantin, Kralın isteği üzerine Tibba dair bir tercüme yapmıştır. Bunu düzenli bir faaliyet haline getirip kurumsallaştıran kişi ise ilk etapta Toledolu Raymond daha sonra ise Peter the Venerable olmuştur. Dolayısıyla Toledo koleksiyonu üç aşamalı bir süreçten oluşmaktadır.

1162 yılında Toledo Koleksiyonu adı altında yapılan bu tercümeler Paris'te Arsenal kütüphanesine aktarılmıştır. 1886 yılında Mlle Marie-Thérése d'Alverny tarafından farkedilip düzenlenmiş ve Arsenal'de el yazmalarının toplanması sonucu Toledo Koleksiyonu günümüze "Arsenal Yazmaları" ismiyle gelmiştir. Parşömenlere yazılar çift sütun şeklinde yazılmış ve yazmaların son bölümü hariç diğer sayfaların arkasında Arapça numaralar kalmıştır. ${ }^{23}$

\footnotetext{
21 Anthony Pym, Tranaltio, disputatio, and the first Latin Qur'an, y.y., 1995-96, s. 173183.

22 James Kritzeck, Peter the Venerable and Islam, Princeton University Press, Princeton, New Jersey, 1964, s.3.

23 Kritzeck, Peter the Venerable and Islam, s. 73.
} 
Kur'an ise özel bir folyada işaretlenmiş, büyük oranda silinmiştir. Ayrıca el yazmasını çoğaltan kişi tarafından yapılan birçok silme ve satır arasında eklemelere de rastlanmaktadır. ${ }^{24}$ Kluni cemaati ${ }^{25}$ tarafından kopyalanan eserler, başka alternatifi olmayan ve şans eseri korunan belgeler olmuşlardır. ${ }^{26}$

Arsenal Yazmalarında Epistola de Translatione sua ve Summa totius heresis Saracenorum çevirileri hariç diğer bütün tercüme edilenler bulunmaktadır. Arsenal yazmasının başlangıcında bulunan kısa konu başlı̆̆ı koleksiyonun diğer yazmalarında bulunmamaktadır. Muhtemelen bu eserleri yazanlar/kopyalayanlar da Poitierslı Peter ve Peter the Venerable'ın kendisi olmuştur. ${ }^{27}$

\section{3-Toledo Okulunda Öne Çıkan İsimler ve Latince'ye Çeviri Ya- panlar}

\section{3.a-Raymond de Sauvetât ${ }^{28}$}

Raymond de Sauvetât, Fransız Benedikten tarikatından Toledo Katedralinin 1125-1152 yılları arasındaki papazıydı.

Bilindiği gibi Toledo, VI. yüzyılın ikinci yarısında Kral Leovigild tarafından Vizigotlar'ın başşehri ilân edilince dinî hayatla birlikte siyasî hayatın da merkezi oldu. Bu dönemde Vizigotlar tarafından gerçekleştirilen Toledo konsilleri, katedrale kattığg hayat ve önem kilise tarihi bakımından ayrı bir yere sahiptir. Toledo'nun Hıristiyanlar tarafından tekrar ele geçirilmesiyle papaz Toledolu Raymond, katedralin eski canlılığını kazanması için tercüme çalışmasına başlamıştır. Raymond'un astrolojiye dair Arapça'dan Latince'ye yaptığ 1 çevirilerle Toledo okulu faaliyetinin ilk nüvesi gerçekleşmiştir. Raymond kaybolan klasik eserlerin tekrar kazanılması ve tanıtılması amacıyla tercüme ekibini oluşturan kişidir. Yahudiler, Hiristiyanlar ve Müslümanlardan yararlanıp İslam düşüncesine dair eserlerin Arapça'dan Latince'ye çevirisi için çaba

\footnotetext{
Kritzeck, Peter the Venerable and Islam, s. 74.

25 Kluni cemaati: (Cluny) Fransa'nın Cluny şehrinde kurulmuş bir Hıristiyan tarikatıdır.

26 Kritzeck, Peter the Venerable and Islam, s. 74.

27 Kritzeck, Peter the Venerable and Islam, s. 74.

28 Francis Raymond de Sauvetât, Raymond of Toledo ve Ruimundo isimleriyle de bilinir. (1130-1187)

http://faculty.washington.edu/petersen/alfonso/esctra12.htm
} 
Toledo Koleksiyonu: Sebepleri ve Sonuçlarıyla İlk Oryantalist Çalışmalar göstermiştir. İlk tercümeler ise daha çok matematik, astronomi ve tıp üzerineydi. ${ }^{29}$

Raymond'un tercüme ekibinde öne çıkan iki isim vardı bunlardan biri Segovia şehrinin başpapazı olan Dominic Gundisalvi (Domingo Gonzalez), diğeri de İtalyan olan Cremonalı Gerard'dır. ${ }^{30}$

\section{3.b-Sevilleli John (John of Seville)}

Bu kişi, Toledo Koleksiyonunun ilk dönemi olarak adlandırdığımız kısımda tercüme faaliyetlerine katılan bir Yahudidir. Sevilleli John'dan başka Avendauth olarak da adlandırılmıştır. Aristo'nun De Anima (On the Soul) adlı eserin tercümesinde Gundisalvus'a yardım etmiştir. Bu tercüme diğerlerinden farklı olarak doğrudan Latince'ye çevrilmemiştir. Çünkü John Latince bilmiyordu, bu yüzden eseri Arapça'dan İspanyolca'ya kelime kelime tercüme etmiştir. Daha sonra da Latince' ye çevrilmiştir. ${ }^{31}$

\section{3.c-Montboissierli Muhterem Peter ${ }^{32}$}

Sistemli bir tercüme faaliyetinin yapılmasına olanak sağlayan Peter, Auvergne'de yaklaşık olarak 1092 yılı dolaylarında doğdu ve Kluni'de 25 Aralık 1156'da öldü. Annesi Raingarde onu 17 yaşında yemin ettiği yer olan Kluni cemaatinin Sauxillanges'taki manast1rına sundu. Yirmi yaşına geldiğinde öğretmen ve Vézelay'daki manastıra başrahip olarak atandı. Bu manastırdan ayrıldıktan sonra Domene manastırına geçti. Gösterdiği başarılar sayesinde 30 yaşına geldiğinde manastırların genel yönetiminden sorumlu kişi olarak seçildi. Avrupa'daki 2000'den fazla reforma muhtaç ibadethaneden sorumlu oldu. Pisa Konsilinin (1134) önemli kişiliklerinden olan St. Bernard'la Innocent II'ye zulmün ortasında taviz vermemesi için cesaretlendirmişlerdir ve 1138 ' de başlayan bölünmenin sonlanacağını ön görmüştür. ${ }^{33}$

Peter the Venerable üstlendiği misyon sebebiyle Avrupa'da bir çok yere çeşitli gezilerde bulundu. Bu geziler sırasında, Hz. İsa'nın ilahlığı, gerçek varlık, Yahudiliğe ve İslamiyete karşı olmayı içeren

\footnotetext{
Bekir Karlığa, İslam Düşüncesinin Batı Düşüncesine Etkileri, İstanbul, 2004, s. 237.

Watt, İslam Avrupa'da, s. 124.

Lynn Thorndike, "John of Seville", Speculum, c.34, no:1, 1959, s. 20-38.

32 Pierre Maurice de Montboisser, Blessed Peter of Montboissier, Peter The Venerable isimleriyle de anılmaktadir.

33 Pierre Auguste Fournet, "Blessed Peter of Montboissier", The Catholic Encyclopedia, c. 10. New York: Robert Appleton Company, 1911. 9, 2014.
} 
söylemlerde bulundu. Bu dinlere mensup olan kişilerin durumu hakkında söylediği ayet ve vaazların yanında Peter'ın görüşlerine de önem vermişlerdir. Bu sebeple Peter belli konular üzerine birçok mektup yazmak durumunda kalmıştır. Peter 1139 yılında İspanya'ya yaptığı gezi sırasında "Muhammedanizm" olarak adlandırdıkları İslamiyete karşı ilgi duymuş ve bunun Hıristiyanlar için doğru öğrenilmesine katkı sağlamak amacıyla bir koleksiyon ve tercüme hareketinin önderliğini üstlenmiştir. ${ }^{34}$

Peter'ın İspanya'ya geliş nedeni ise Avrupa'daki en büyük bağışı yapan Alfonso VII'nin bu bağışı kesmesidir. Peter, Alfonso VII'yi tekrar bağışa ikna etti. Ancak bu kez eski Müslüman topraklarından altından daha değerli bir şey istedi. Bu da bağışını kiliseye değil Toledo'da gerçekleştirilecek olan tercüme faaliyetlerine yapmasıydı. Alfonso VII'nin Toledo okuluna sağladığı ekonomik katkı sonucu okul aynı zamanda Alfonso Okulu olarak da anılmaya başlanmıştır. ${ }^{35}$

Peter, kimsenin İslam'ı anlamaya ve öğrenmeye çalışmadığı bir dönem olan Haçlı Seferleri sırasında İslamiyetin ne olduğunun anlaşılmasını sağlayan kişidir. ${ }^{36}$

\section{3.d-Kettonlu Robert (Robert of Ketton)}

Kettonlu Robert'in hayatı hakkında çok geniş bilgiye sahip değiliz. Bir İngiliz olmasına rağmen Barselona'ya yerleşmiş ve orada Tivolili Plato' dan 1136 yılında ders almıştır. Robert'in uzmanlık alanı astronomi ve geometri olmasına rağmen Toledo Koleksiyonu'nda Kur'an-1 Kerim'in tercümesi görevini üstlenmiştir. Bu vesileyle papaz olma umudunu taşımış ama ona sadece başdiyakozluk görevi verilmiştir. ${ }^{37}$

O, 1144 yılında Simya ile ilgili bir kitap tercüme etmiştir. Ertesi yıl el-Harizmi'nin el-Kitab el-muhtasar fi hisab el-cebr ve-el-mukâbele

\footnotetext{
Fournet, "Blessed Peter of Montboissier".

Anthony Pym, Tranaltio, disputatio, and the first Latin Qur'an, s. 173-183.

Şaban Ali Düzgün, "Oriental Studies and Conception of Islam During the Crusade Period", International Symposium on Orientalism held in Oran, Cezayir, 1999, s.164.

37 Kritzeck, Peter the Venerable and Islam, s. 62. (bkz. J. P. Kirsch, s.v. "Archdeacon", Thr Catholic Encylopedia, c. I, New York, 1907, s.693-94.
} 
Toledo Koleksiyonu: Sebepleri ve Sonuçlarıyla İlk Oryantalist Çalışmalar adlı cebir eserini Liber algebrae et Almucabo adiyla Latince'ye çevirmiştir. ${ }^{38}$ Eserin geniş çapta kullanılmasıyla "Avrupa'nın cebir bilgisi başlamıştır" ${ }^{39}$ Kettonlu Robert, Londra'da 1150' de usturlab üzerine yapılmış bir tercümeyi gözden geçirdi. Battani ve Zerkani'nin çalışmalarına dayanan Londra'nın boylamı hakkındaki astronomi cetvelini tamamladı ve Bathlı Adelard tarafından tercüme edilen Harizmi'nin cetvelini yeniden inceledi. ${ }^{40}$

\section{3.e-Dalmatialı Herman (Herman of Dalmatia) (1100-1160)}

Herman Aleman, Hermannus Teutonicus veya Germanicus ${ }^{41}$ Herman Dalmatin, Herman of Carinthia isimleriyle anılmış ve 11001160 yılları arasında yaşamıştır. Ayrıca Latince'de Sclavus Dalmata, Secundus olarak da bilinmektedir. Herman filozof, gökbilimci, astrolog, matematikçi, yazar ve Toledo Koleksiyonunun tercüme komisyonunda yer almış bir Almandır. Papaz olduğu sanılmaktadır. ${ }^{42}$ Herman, Bathlı Adelard, Sevilleli John, Cremonalı Gerard (11141187) ve Tivolili Plato (1134-1145) gibi tercümanların arasında XII. yüzyılın en iyi Arapça'dan Latince'ye ve Yunanca'ya tercüme yapan kişisi sayılmıştır. Orta Avrupa'nın astronomiye dair bilgisinin artmasında ve yayılmasında Herman'ın tercümelerinin önemli rolü olmuştur. ${ }^{43}$

Herman Kettonlu Robert'le Fransa'da eğitimleri sırasında tanışmış ve İspanya'ya bir süreliğine birlikte gelmiştir. Arapçadan tercümeler açısında önemli bir ülke olan İspanya'da Tivolili Plato'dan 1136 yılında ders alarak tercüman oldular. ${ }^{44}$ Burada Kur'an tercümesine katkısının yanında asıl olarak De generatione Muhamet et nutritura eius ve Doctrina Muhamet ${ }^{45}$ isimli iki kitabın tercümesini yapmiştır.

38 Thomas E. Burman, "Tafsir and Translation: Traditional Arabic Qur'an Exegesis and the Latin Qur'ans of Robert of Ketton and Mark of Toledo", Speculum, c. 73, no. 3, 1998, s. 704.

39 Kritzeck, Peter the Venerable and Islam, s. 63.

$40 \quad$ Kritzeck, Peter the Venerable and Islam, a.g.y.

${ }^{41}$ http://faculty.washington.edu/petersen/alfonso/esctra12.htm

42 Kritzeck, Peter the Venerable and Islam, s.66.

43 Karlığa, İslam Düşüncesinin Batı Düşüncesine Etkileri, s. 249.

44 Kritzeck, Peter the Venerable and Islam, s. 66.

45 Muhammed'in Neslini Anlatan Kitap ve Muhammed'in Öğretisi. 
Herman Toledo Koleksiyonundaki tercümelerinden başka Sahl b. Bişr' in astronomi risalesini 1138de, Harizmi ve Ebu Ma'şer'in astronomik cetvellerini ve Majiriti'nin tercüme edip üzerine yorum yaptığ 1 Ptolemy'nin Planisphere adlı eserin tercümesini 1140 'da tamamlamıştır. ${ }^{46}$ Aristoteles'in Aethica Nichomachea 1240 'ta, Topikleri, Retoriki, Poetiki üzerine yaptığı şerhi de 1256 yılında tercüme etmiştir. ${ }^{47}$

Herman'ın Avrupa tarihine kattığı en önemli çalışması De Essentiis'dir. Tercümelerden sonra coğrafi gözlem yapıp söz konusu eserini tamamlamak için bir süre daha Toledo' da kalmıştır. ${ }^{48}$ Bu eserin özelliği ise, hareket halindeki yıldızların fiziksel etkilerini açıklamasıdır. Ayrıca eserde Tanrı'nın evreni ve insanı yaratması konusunda fiziki açılamalarda bulunur. ${ }^{49}$ Eserinin oluşma aşamasındaki çalışmalarına kaynaklık eden Arapça'dan Latince'ye tercüme edilen eserlerin yaptığı katkıyı kitabında anmıştır. ${ }^{50}$

1142 'den sonra İspanya'dan ayrıldığına dair bir belge bulunmamaktadır. Peter the Venerable, Dalmatialı Herman'ın bilginler arasında çok zeki ve yazılı edebiyata dair yetenekli biri olduğunu belirtmiştir. ${ }^{51}$

\section{3.f-Toledolu Mark (Mark of Toledo)}

Toledo Koleksiyonunda Kur'an-1 Kerim'i tercüme edenler arasında yer almıştır. Ayrıca Hipokrat'ın “De aere aquis et locis" (Hava, Su, Toprak) isimli eserini, Huneyn b. İshak'ın düzenlediği "De tactu pulsus, De utilitate pulsus, Se motu membrorum, De motibus liquidis" Galen'in dört risalesini tercüme etmiştir. Yine Huneyn b. İshak'ın Isagoge ad Tegni Galieni ve Müslümanların birçok risalesiyle Biyolojiyle ilgili Yunanca bir eseri tercüme etmiştir. ${ }^{52}$

46 Kritzeck, Peter the Venerable and Islam, s. 66.

47 Metin Özdemir, “İbn Rüşd'ün Aristo'nun Topikleri, Retoriki, Poetiki üzerine üç kısa şerhi", KADER, 7/2, 2009, s. 89.

48 Kritzeck, Peter the Venerable and Islam, s. 67.

49 Bruce Eastwood, "America De essentiis by Hermann of Carinthia; Charles Burnett", Speculum, Medieval Academy of America, c.59, no.4, 1984, s. 912.

50 Eastwood, "America De essentiis by Hermann of Carinthia; Charles Burnett", Speculum, s. 913.

51 Kritzeck, Peter the Venerable and Islam, s. 66. (bkz. Clerval, "Hermann le Dalmate, "Compte rendu du Congrés scientifique international des Catholiques, c. II, 1891, ss. 163-69).

52 http://faculty.washington.edu/petersen/alfonso/esctra12.htm 


\section{3.g-Toledolu Peter (Peter of Toledo)}

Toledolu Peter, asıl adı Peter Alfonsi olan Toledolu bir âlimdir. Toledo'nun ve diğer şehirlerdeki katedrallerin parşömenlerini ve belgelerini toplamakla görevliydi. Bu vesileyle Peter the Venerable onun hakkında bilgi sahibi olmuş ve Poitersli Peter ile birlikte, Kindi'nin Apoloji adlı Müslümanlara reddiyesini Latinceye tercüme etmelerini istemiştir. ${ }^{53}$

\section{3.h-Puvatyalı Peter (Peter of Poitiers)}

Puvatyalı Peter Klunili bir rahipti. Aynı zamanda St. John'lu Peter olarak da anılmaktaydı. Peter the Venerable ile aralarında iyi bir dostluk vardı. Toledo Koleksiyonunun sekreterya görevi ve diğer önemli görevlerinde Peter the Venerable ile birlikte çalışmıştır. ${ }^{54}$

\section{3.i-Muhammed}

Bu kişi hakkında kesin olan tek bilgimiz onun Müslüman olduğudur, isminde bile netlik yoktur. Onun görevi diğer tercümanlara Arapça kelimelerinin anlamını İslami metafiziğe uygun olarak çevirmelerine yardım etmek olmuştur. ${ }^{55}$ Bunun yanında Robert'in yaptığ1 Kur'an'ın tercümesini ve Toledolu Peter'in Toledo Koleksiyonuna yazdığı dipnotlarını kontrol görevlerinde bulunmuştur. ${ }^{56}$

\section{3.j-Micheal Scot (Scott)}

Toledo'ya 1217 yılında gelmiştir, buradan Bologna ve Roma'ya gitmiştir. Sicilya sarayında İslam ilmine ilgi duyan II. Frederick'in isteği üzerine bazı tercümeler yapmıştır. Scott'un önemli çevirileri; Aristo'nun eserleri, İbn Rüşd'ün bu eserlere yaptı̆̆ 1 şerhler ve İbn Sina'nın tabiat bilgisi hakkındaki eseridir. ${ }^{57}$

Bahsettiğimiz bu kişilerden başka; Cremonalı Gerard, Dominicus Gundissalinus gibi isimlerin yanında Yahudi ve Hıristiyanlardan oluşan daha birçok isim eklemek mümkündür. ${ }^{58}$

\footnotetext{
Kritzeck, Peter the Venerable and Islam, s. 56.

Kritzeck, Peter the Venerable and Islam, s. 59.

Kritzeck, Peter the Venerable and Islam, s. 68.

Kritzeck, Peter the Venerable and Islam, s. 69.

Watt, İslam Avrupa'da, s. 125.

Karlığa, İslam Düşüncesinin Batı Düşüncesine Etkileri, ss. 243-293.
} 


\section{Tercümede Öne Çıkan Eserler}

\section{1-Felsefe Alanındakiler}

4.1.a-Aristo'nun Organon Eseri: Bir bölümü doğrudan Yunanca'dan, bir bölümü de Arapça'dan tercüme edilip, XII. yüzyılda tamamlanmıştır. ${ }^{59}$

De Anima: (Can Üzerine) Sevilleli John tarafından tercüme edilmiştir.

4.1.b-Farabi'nin eseri: İhsâ'u'l-'ulûm: Cremonalı Gerard ve Dominicus Gundissalinus tarafından De syllogismo, adıyla tercüme edilmiştir. 60

4.1.c-İbn Sina'nın eseri; Eş-Şifa (Suffcientia): Dominicus Gundissalinus İbn Davud'un katkısıyla Arapça'dan Latince'ye tercüme etmiştir. Eserin başında İbn Davud tarafından yazılmış bir takdim yazısı bulunmaktadır. Bu yazıda hem Toledo' daki tercüme faaliyetlerinden hem de orada tercüme yapan mütercimlerden bahsetmektedir. ${ }^{61}$ İbn Davud'un yazdı̆̆ 1 takdim yazılarından birinin girişi şu şekildedir:

"İşte doğrudan doğruya sizin direktiflerinizle Arapça' dan çevrilmiş bulunan bu eserde ben, her kelimeyi halk dilinde (Roma dili; Katalanca) söylüyordum, Piskopos Dominicus da olabildiğince onu Latince' ye çeviriyordu." 62

Eserin tamamı olmasa da parçalar halinde bazı bölümleri günümüze ulaşmıştır.

\section{2-Temel Referanslarla İlgili Olanlar}

4.2.a-The Qur'an (Kur'an-1 Kerim, Lex Mahumet pseudoprophete, Law of Muhammad the false prophet): Toledo Koleksiyonunun en önemli parçasını oluşturan Kur'an tercümesi 1142 yılında Kettonlu

59 Watt, İslam Avrupa'da, s. 137.

60 Özdemir, "Tuleytula”, DİA, c. 41, s. 366. Metnin orijinali için bkz: Al-Fārābī, De syllogismo, Incipit 925: "Nostra in hoc [libro] intentio est famosas scientias...." (L. Thorndike ve P. Kibre, A Catalogue of Incipits of Mediaeval Scientific Writings in Latin, 2. ed. [Cambridge, Mass., 1963].)

61 Karlığa, İslam Düşüncesinin Batı Düşüncesine Etkileri, s. 238. Takdim yazısı için; bkz. G. Verbeke, Introduction sur la Doctrine Psychologique d'Avicenne, Brill, Leiden, 1968, (Avicenna Latinus, Liber de Anima önsözü), 91.

62 Karlığa, İslam Düşüncesinin Batı Düşüncesine Etkileri, s. 238. (Bkz. Metin için; Simon van Riett, Avicenna Latinus, Liber de Anima, 1994, s.103). 
Toledo Koleksiyonu: Sebepleri ve Sonuçlarıyla İlk Oryantalist Çalışmalar Robert tarafindan tercüme edilmeye başlanmış ve 1143 yılında tamamlanmıştır. Robert tercümenin önsözünde tercüme yaparken çok zorlandığını ifade etmiş ve Toledolu bir Müslüman olan Muhammet'ten yardım almıştır. ${ }^{63}$

Bu tercümenin özelliği ilk defa Kur'an'ın tümünün bir yabancı dile çevrilmiş olmasıdır. Daha önceki zamanlarda da Kur'an'ın bazı çevirilerinin yapıldığı iddia edilmektedir. Ancak bunların Kur'an'ın bütünü yerine bazı bölümlerinden ibaret olduğu bilinmektedir. ${ }^{64}$

Robert Kur'an'1 olduğu gibi tercüme etmek yerine bir takım değişiklikler yapmıştır. Bunların başında sureleri tekrar bölümlere ayırmak gelmektedir. Mesela Bakara suresinin üç ayrı bölüme ayırmiş ve bu sureden başka yine uzun gördüğü sureleri de bölmekten çekinmemiştir. Kur'an tercümesi bittiğinde ise ortaya fazladan dokuz sure çıkmıştır. ${ }^{65}$

Robert Kur'an'1 üst seviyede, asillere dönük bir Latinceyle tercüme etmiştir. Bu Batıda Kur'an'1n kıymetini arttıran önemli bir faktör olmuştur. Daha sonra Kur'an-1 Kerim Toledolu Marcus tarafından ikinci kez Latince' ye tercüme edilmiştir. ${ }^{66}$

\section{2.b-Fabulae Saracenorum (Sarazenlerin Hikâyeleri, Kısas-1 En-} biya): Toledo Koleksiyonunda ilk tercüme edilen eserdir ve Chronica mendosa et ridicula Saracenorum (Sarazenlerin yanlış ve komik hikâyesi) alt başlığ1 verilmiştir. Kettonlu Robert tarafından tercüme edilen eser, yaratma, önceki peygamberlerin hayatı ve Hz. Muhammed'in hayatı hakkında bilgi veren hadislerin derlenmesinden oluşmaktadır. ${ }^{67}$ Eser, Tanrı'nın kendi eliyle yarattı̆̆ı dört şeyi ayetlere

\footnotetext{
63 Kritzeck, Peter the Venerable and Islam, 97.

64 Mustafa Yazıcı, Haçlı Savaşları Döneminde Müslümanlar ve Hıristiyanlar Arasındaki Teolojik Ilişkiler: Toledo Okulu Örneği, Basılmamış Yüksek Lisans Tezi, Ankara, 2003, s. 100. (Bkz. A. Mingana, An Ancient Syriac Translations of the Kur'an Exhibiting New Verses and Variants, Bulletin of the John Rylands Library, Manchester, c. IX, 1925, s. 188-235).

65 Kritzeck, Peter the Venerable and Islam, 99.

66 Karlığa, İslam Düşüncesinin Batı Düşüncesine Etkileri, s. 238. (Bkz. Emile Brehier, Historie de la Philosophie, c. I, Paris, 1928, s. 639; Francesco Gabrieli, "The Transmission of Learning and Litterary Influences to Western Europe", The Cambridge History of Islam, II/B, Cambridge, 1970, s.854-856).

67 Kritzeck, Peter the Venerable and Islam, s. 75.
} 
atıfta bulunan bir açıklamayla başlamıştır. ${ }^{68}$ Bunlar, "dünyanın başından sonuna kadar olan her şeyi yazan": "Kalem", (The Pen), Hz. Âdem (Adam), Kürsi (Throne), Cennet (Paradise). ${ }^{69}$

İlk bölüm olan yaratma bahsinde Hz. Âdem'in yaratılırken Allah'ın çok renkli tozları topladığını, bu yüzden insanların renginin bazen beyaz bazen de siyah olarak değiştiğini iddia etmektedir. Aynı zamanda insanın anne karnındaki geçirdiği süreden bahseden ve doğum zamanı geldiğinde ise bir meleğin gelip o kişinin ruhuna nefes üflediği ve onun faziletli olup olmayacağını veya cennete mi yoksa cehenneme mi gideceğini belirlediğini anlatan hadis yer alır. ${ }^{70}$

Eserin ikinci kısmında peygamberlerin hayatlarından çok onların hakkında kronolojik bilgiye yer verilmiştir. Gönderilen peygamber sayısının toplamda 12000 olduğunu; bunlardan 350'sinin Yahudi 4'ünün de Arap olduğu, Hz. Musa'nın ilk Yahudi peygamber Hz. İsa'nın ise son Yahudi peygamber olduğu ve Arap, İran, Yahudi ve Roma'nın en akıllı ırklar oldukları bildirilmektedir. Ayrıca Hz. Muhammed'in nurunun Hz. Âdem yaratılmadan 2000 yıl önce yaratıldığını ve peygamberler aracılığıyla nesilden nesile aktarılarak ona ulaştığı anlatılmaktadır. ${ }^{71}$

Son kısım olan üçüncü bölümde Hz. Muhammed'in hayatı ve halifeler döneminden bahsetmektedir. Hz. Muhammed annesinin vefatından sonra dedesinin himayesine girmiş ve aynı zamanda onu İsrafil adlı melek korumaya başlamıştır. Daha sonra İsrafil'in görevi Cebrail'e verilmiştir. Peygamber olduktan sonra Medine'ye olan hicreti ve müşriklerle savaşı da aktarılmaktadır. Hz. Peygamberin vefatını konu edindikten sonra da Hulefâ-i Raşid dönemini ve Muaviye'nin halifeliğini anlatıp eser tamamlanmıştır. ${ }^{72}$

Fabulae Saracenorum'un hangi Arapça metinden tercüme edildiği tespit edilememiştir. Bunların en temel sebebi olarak da, tercüme sırasında Kettonlu Robert'in hadislerin senetlerini kasıtlı

\footnotetext{
68 Kalem 68/1; Bakara 2/256; Rahman 55/54, 72; Vak1a 56/15-22, 27-33.

69 Kritzeck, Peter the Venerable and Islam, s. 76.

70 Kritzeck, Peter the Venerable and Islam, s. 77. (İbn Mâce Ebu Abdullah Muhammed b. Yezid el-Kazvini, Sunnenu İbn Mâce, Daru'l-İhyâi'l-Kütübi'l-Arabiyye, 1953, 10)

71 Kritzeck, Peter the Venerable and Islam, s. 79.

72 Kritzeck, Peter the Venerable and Islam, s. 80.
} 
olarak yazmamış olmasıdır. Çünkü ona göre bu metni okuyan Latinlere Arapça isimlerin yabancı olması ve dolayısıyla onlara hiçbir şey ifade etmeyeceğinden gerek görmemiştir. ${ }^{73}$

Fabulae Saracenorum, Arsenal yazmalarında 11 bölümden oluşan bir eser şeklinde korunmuştur. Fakat eserin orijinalinin daha hacimli olduğu düşünülmektedir. Çünkü Fabulae Saracenorum, aslında birkaç kitabın bir derlemesi şeklinde tercüme edildiği sanılmaktadır. Taraflı bir özetlemeyle Arsenal yazmalarında bazı bölümlerin kesildiği varsayılmaktadır. Ancak Arap literatürünün çok zengin olması sebebiyle metinde geçen kısımları İslam düşüncesi içinde bulmak çok da zor olmamaktadır. ${ }^{74}$

\section{2.c-Liber Generationis Mahumet (Muhammed'in Neslini Anla- tan Kitap, De generatione Muhamet et nutritura eius): Koleksiyo-} nun ikinci tercüme edilen eseridir. Dalmatialı Herman tarafından tercüme edilmiştir. Sa'd bin Ömer'in Kitabu Neseb Rasulillah adlı eserinin Latince tercümesidir. Fabulae Saracenorum gibi bu kitap da yaratmayla ilgili birçok anlatıyı ve önceki peygamber ve resullerin hayatlarını içerir. Kitabın asıl amacı Hz. Âdem'den Hz. Muhammed'e kadar gelen mucizevi nurdur (Nur-u Muhammed). Hz. Muhammed'in doğumu ve çocukluğuyla ilgili Hıristiyanlıkla paralel olan olaylar iliştirilmiştir. Robert'in aksine Herman isnad zincirini vermiş ve böylece tercüme yapılan eserin orijinal halinin bulunmasına olanak sağlamıştır. ${ }^{75}$

Eser İslam edebiyatındaki peygamberlik nuru ve mevlid doktrinlerini ele almaktadır. Nur-u Muhammed inancı 8. yüzyılın başlarında ortaya çıkmıştır. Esere göre bu ifadenin ortaya çıkışı da Kur'an'daki derin düşünmeye, Farslı uyarıcıya, Gnostik-Hermetik(Sihirli) yazılara ve son olarak da Hellenistik felsefeye atfedilir. Bazı Hıristiyanların da nur kavramını kullanmaları sebebiyle bu durum aynı akarsudan alınan suya benzetilmiştir. ${ }^{76}$

Eserde "peygamberlik nuru" ifadesini kullanan ilk kişi Şii şair Kümeyt el-Esedi (ö. 126/744) olduğu geçmektedir. Şiirinde nurun

\footnotetext{
Kritzeck, Peter the Venerable and Islam, s. 75.

Kritzeck, Peter the Venerable and Islam, s. 76.

Kritzeck, Peter the Venerable and Islam, s. 84.

Kritzeck, Peter the Venerable and Islam, s.84.
} 
Hz. Âdem'den Hz. Muhammed'e ve ondan da Hz. Ali'nin ailesine geçtiğini anlatmıştır. ${ }^{77}$

Hz. Peygamberin doğumunda ve çocukluğunda mucizevî olayların olduğunu anlatan şiirlere de mevlit denilmiştir. Bunu da şiirlerinde ilk olarak kullananlar ve bu kültürün getirdiği bir sonuçla bu durumu kutlamaya çevirenler Mısır'daki Fatımiler olmuşlardır. $\mathrm{Bu}$ kutlama daha sonra bir gelenek halinde diğer toplumlara geçmiştir. Bu eserin yazıldığı zamanda henüz İspanya'da kutlanmaya başlanmamış ancak daha sonra oraya geçmiş olması da muhtemeldir. ${ }^{78}$

\section{2.d-The Doctrina Mahumet (Muhammed'in Öğretisi, Muslim}

Catechism): Dalmatialı Herman'ın tercüme ettiği ikinci eserdir. Eserin orijinal ismi Mesâ'il 'Abdillah ibn Selam'dir ve başka başlıklar altında bu eserden bulunmaktadır. ${ }^{79}$ Eser hayali bir diyalog, bilmece ve kurnazca hazırlanmış soru-cevaplarla kurgulanmıştır. ${ }^{80}$

Eser Hz. Peygamberin Medine'de sahabeleriyle otururken Cebrail'in gelip, ona soru sormak için gelen 4 Yahudi lideri haber vermesiyle başlamaktadır. Abdia ${ }^{81}$ isimli Yahudi'nin liderliğinde gelen kişilerin, Hz. Peygambere soru sorması ve onun da cevap vermesi şeklinde gelişen diyalog anlatılmaktadır. Bu diyalogda geçen bazı soru ve cevaplar şu şekildedir:

“Abdullah: Sen nebi misin yoksa resul mü?

Hz. Peygamber: Bu soruya ayetlerle cevap verir.

Abdullah: Senden önce gelen peygamberler hakkında ne düşünüyorsun?

\footnotetext{
Kritzeck, Peter the Venerable and Islam, s.84.

Kritzeck, Peter the Venerable and Islam, s. 85.

79 Kritzeck, Peter the Venerable and Islam, s. 89. Bu eserin İngilizce ve Felemenkçe çevirileri için; N. Davis, The Errors of Mohammedanism Exposed: veya A Dialogue between the Arabian Prophet and a Jew, Malta, 1847; G. F. Pijper, Het boek der duizend vragen, Leiden, 1924.

80 Kritzeck, Peter the Venerable and Islam, s. 89.

81 Görüşmenin sonunda Müslüman olduğu için Abdullah adını almıştır. Metinin devamında Abdullah olarak anılmaktadır.
} 
Toledo Koleksiyonu: Sebepleri ve Sonuçlarıyla İlk Oryantalist Çalışmalar

Hz. Peygamber: hepsinin imanı ve kuralları tek/aynıdır. Fakat muamelatlarla ilgili kısım farklıdır. Cennete girmek için ön şartın ise hakiki iman olduğunu vurgulamıştır." 82

"Hz. Muhammed, daha sonra "ol" emriyle çamurun nasıl insan haline geldiğini anlatır. "İki meleğin insanların iyilik veya kötülüklerini yazmak için görevlendirildiğini, Allah'ın yeşil zümrütten bir levhası olduğunu ve 500 yıllık bir seyahat boyunda ve 80 yıllık bir seyahat eninde olan, inciden bir kalemle yeryüzündeki ve gökyüzündeki olmuş ve olacak her şeyin yazılı olduğunu söylemiştir. Ay ile güneşin aslında aynı miktarda ışık sahibi olarak yaratılmışken Cebrail'in yanlışlıkla kanadıyla aya dokunması sebebiyle ayın ışığının azaldığını anlatmıştır." 83

Metne göre Abdullah daha sonra; "Güneşi bir kez görüp bir daha görmeyecek yer neresidir?" gibi bilmece tarzı sorulara devam eder. Nihayetinde Allah'tan başka ilah olmadığına ve Hz. Muhammed'in O'nun peygamberi olduğuna iman ettiğini beyan etmesiyle eser tamamlanmıştır.

Tercüme edilen bu eserde birçok uydurma rivayete rastlanmaktadır. Bunları Kur'an'1 veya sahih kabul edilen eserleri temel aldığımızda bir karşılığını bulmak mümkün değildir.

\section{2.e-Epistola Saraceni et Rescriptum Christiani (Kindi'nin Apo-} lojisi, Apologia for Christianty): Risalat Abdillah ibn-İsmail el-Haşimi ila 'Abdu'l-Mesih İbn İshak el-Kindi veya Risalat el-Kindi ila el-Haşimi adlı eserin Latince tercümesidir. İslam dünyasında Kindi'nin Apolojisi adıyla bilinen metin Toledo Koleksiyonunda son tercüme edilen eserdir ve Toledolu Peter ile Poitiersli Peter tarafından tercüme edilmiştir. ${ }^{84}$

82 Kritzeck, Peter the Venerable and Islam, s. 90-91.

83 Yazıcı, Haçlı Savaşları Döneminde Müslümanlar ve Hıristiyanlar Arasındaki Teolojik Illişkiler: Toledo Okulu Örneği, s. 95. (bkz. Kritzeck, Peter the Venerable and Islam, s.92.)

84 Düzgün, "Oriental Studies and Conception of Islam During the Crusade Period", International Symposium, s.164. Eserin İngilizce tercümesi için; N.A.Newman, The Early Christian-Muslim Dialogue, A collection of documents from the first three Islamic centuries (632-900 AD.); yorumlarla birlikte İngilizce tercüme için; Interdiciplinary Biblical Research Institute, Pensylvania 1993,355-547. Bahsi geçen tercümanlarla ilgili detaylı bilgi için; Islamochristiana, 5, 1979, s. 312-13. 
Eser bir rivayete göre Me'mun'un sarayında biri Hıristiyan diğeri Müslüman olan iki kişinin aralarında geçen mektupların derlenmiş halidir. Ayrıca halifenin bu mektuplaşmayı duyduğunda huzurunda okunmasını emrettiği de rivayet edilir. ${ }^{85}$ Diğer bir rivayete göre ise böyle bir olay yaşanmamış ve hayali olarak kurgulanmış bir diyaloğun kelimelere dökülmüş halidir. Ve eserin Me'mun zamanında değil miladi onuncu yüzyılda Biruni'nin (ö.1048) son zamanlarında yazdığ 1 da iddia edilenler arasındadır. ${ }^{86}$

Mektuplarda özel olarak değinilen konular, Hz. Muhammed, Kur'an ve Hz. Muhammed'in yaptığı savaşlar olmuştur. Bu üç konu da Hıristiyanların ortaçağlarda İslam'a karşı yazdıkları reddiyeler için bir kaynak teşkil etmiştir. ${ }^{87}$

Peter the Venerable bu tercümenin girişine, Summa Totius Haeresiis Sarracenorum adıyla bir önsöz yazmıştır. Bu yazı da Peter, Müslümanlığın Hıristiyanlığın sapması olduğunu iddia etmiştir. ${ }^{88}$

Apoloji'nin son kısmında dikkat çeken bir olay anlatılmaktadır. “Halife Me'mun Müslüman ve Hıristiyan iki tartışmacının risalelerinin kendisine okunmasını istedi ve sonuna kadar sessizce dinledi. Ardından Müslüman polemikçiyle ilgili olarak şunları dile getirdi: "Kendisini ilgilendirmeyen ve kabiliyetini aşan meselelerle neden ilgileniyor? Me'mun şöyle devam etti: "Hıristiyan'a gelince, ona karşı bir delilimiz yok. Dininin doğruluğu konusunda kesin kanaat sahibi olmamış olsaydı, ona bağlı kalmazdı. İki tür din vardır: biri bu dünyaya ait din, diğeri ise ahirete ait olan. Bu dünyanın dini Mazdeklerin dinidir ve Zerdüştün öğretisine dayanır. Diğeri ise H1ristiyanların dinidir, İsa Mesih'in mesajına dayanır." Me'mun şu sözlerle konuşmasını bağladı: "Ama gerçek din tevhid dinidir ve

85 Sabire Abay, Müslümanlarla Hiristiyanlar Arasındaki Teolojik İlişkilerin İlk Döneminde Abdülmesih El-Kindi'nin Abdullah b. İsmail El-Haşimi'ye Reddiyesi Örneği, Basılmamış Yüksek Lisans Tezi, Ankara, 2002, s.196. (Bkz. Abd al-Mesih b. Ishak alKindi, "The Apology of Al-Kindi", ed. Anton Tien, The Early Christian - Muslim Dialogue, A Collection of Documents from The First Three Centruies (632-900) Translation with Commentary içinde, ed. N. A. Newman, Pennsylvania, 1993, s. 355-553). Yazıcı, Haçlı Savaşları Döneminde Müslümanlar ve Hıristiyanlar Arasındaki Teolojik İlişkiler: Toledo Okulu Örneği, s.107. 
Toledo Koleksiyonu: Sebepleri ve Sonuçlarıyla İlk Oryantalist Çalışmalar efendimiz (Hz. Muhammed) tarafından getirilmiştir. Bu hem bu dünyayı hem de ahireti birleştiren dindir." 89

Arsenal yazmalarına bakıldığında metindeki son iki cümlenin üstünün çizildiği görülmüştür. Bu sebeple pasajda dikkatimizi çeken, esere tercümede yapılan tahriftir. Çünkü sonraki araştırmacılar tarafından ispat edildiği üzere Me'mun'un İslam'a dair söyledikleri Arsenal yazmalarında mevcutken, diğer baskılarda yoktur. Cümleyi yok sayanın kim olduğu belli değildir. Ama eserin Toledo'da Latince'ye tercümesinden sonra Kluni'ye geldiğinde yapılan düzeltmeler sırasında olabileceğine dikkat çekilmektedir. İlginç olan ise cümlelerin üstü çizili olduğu halde yine de yazılar okunabilmesine rağmen eseri çoğaltan kişinin bunu göz ardı etmesidir. ${ }^{90}$

4.2.f-Liber Scalae Machometae: Kastille Kralı Alfonso'nun isteği üzerine Seville de tercüme edilmiştir. Eserde Hz. Peygamberin miraç hadisesi ele alınmıştır. ${ }^{91}$ Eser Hz. Muhammed'in hayatını ve doktrininin abartılı ve hurafe dolu yanlarını konu edinmiştir. ${ }^{92}$ Toledolu Abraham (Al-Faquin) tarafından Arapçadan Kastilya diline tercüme edilmiş daha sonrada Liber Scale Machometi/ae ismiyle Latinceye tercüme edildiği bilinmektedir. Ayrıca Dante'nin İlahi Komedya'yı yazarken bu eserden yararlandığı da tahmin edilmektedir. ${ }^{93}$

4.2.g-Summa Totius Haeresis Saracenorum: Peter the Venerable' $1 n$ tercümeler neticesinde İslam'a dair kendi yorumunu ele aldığ dir. İslam esaslarının özeti şeklinde olan esere daha sonra da Liber contra sectam sive haeresis Saracenorum isimli bir şerh yazmıştır. Bu ikisi de Kluni Külliyatı olarak geçmekte ve İslam hakkında Latince

89 P. S. van Koningsveld, The Apology of al-Kindi, Religious polemics in context: papers presented to the second international conference of the Ladien institute for the study of religions, ed. Tl. Hettema \& A van der Kooiji, Leiden, 2000. s. 3. (G. Tartar, Dialogue Islamo-Chrétien sous le Calife Al-Ma'mûn (813-834). Les Epitres d'Al-Hâshimî et d'Al-Kindî, Strassbourg, 1977, 6vd.)

90 Koningsveld, The Apology of al-Kindi, Religious polemics in context: papers presented to the second international conference of the Ladien institute for the study of religions, s. 3 .

91 Karlığa, İslam Düşüncesinin Batı Düşüncesine Etkileri, s. 240.

92 Karlığa, İslam Düşüncesinin Batı Düşüncesine Etkileri, s. 116. (Jose Munoz Sendino, La Escala de Mahoma, Madrid, 1949, s.16)

93 Karlığa, İslam Düşüncesinin Batı Düşüncesine Etkileri, s. 116. (Bkz. Miguel Asin Palacios, La Escatologia Musulmana en la Divina Comedia, Madrid, 1961; eserin Arapça çevirisi için Celâl Mazhar, Eseru'l-İslam fi'l-Komedya'l-İlahiyye, Kahire, 1980. 
yazılmış ilk oryantalistik eser olma özelliğine sahiptir. Bu eseri takiben yine çevirmenler arasında olan Yahudi Petro Alfonso'nun Diayalog'lar adlı eseri gelmektedir. ${ }^{94} \mathrm{Bu}$ iki eserin ortak özelliği o zamanlarda İslam'a dair bilinen yanlışlarını bu eserlerde tekrarlanmamış olmalarıdır. Diyaloglar kitabından ziyade Peter'ın kitabı, Avrupa'da İslam'ın yeni imajına katkıda bulunmuştur. Bu eseri desteklemek adına başka birçok çalışma yapıldıysa da bunlar arasinda en önemli olanı Ricoldo de Croce'e (ö.1321) ait olan Improbatio alchorani (Sarazenlere ve Kur'an'a Karşı Tartışma) adlı eser olmuştur. ${ }^{95}$

Latinceye yapılan tercümelerde bazı hatalar yapılmıştır. Bunlardan bazıları; çevirmenin yeterince Arapça'yı iyi bilmemesi, genel anlamda İslam'a dair bilgisinin yetersizliği, özelde ise Kur'an, nübüvvet ve erken dönem İslam'ına ilişkin bilgi eksikliği olarak sıralanabilir. Örneğin; Hz. Peygamber' in "Komşunuzu dini ve inancında dolayı sevin" hadisini "Arapları dinleri ve inançları sebebiyle sevin" şeklinde tercüme edilmiştir. Bu yanlış tercüme İslam'ın, Arap dini olduğu basmakalıp düşüncesini destekleyerek İslam'ın evrensel olduğu gerçeğinin gölgelenmesine sebebiyet vermiştir. ${ }^{96}$

\section{Toledo Koleksiyonunun Doğurduğu Sonuçlar}

Toledo koleksiyonu Batı dünyası için ciddi sonuçlar yaratmıştır. Bunlardan bazılarını şöyle sıralayabiliriz:

i. Tercümelerin Sona Ermesi Sonucu Avrupa'nın İlk Rönesans' 1 ın ${ }^{97}$ Başlamasi: Toledo koleksiyonunda oryantalistik faaliyet olarak temelde yedi kitap tercümesi yapılmıştır. Ancak bu projeye katılan tercümanların kendilerinin yaptıkları diğer tercümeleri dikkate aldığımızda burada 7 kitaptan çok daha fazlası olduğu görülmektedir. Özellikle astronomi, matematik, İslam felsefesi ve Arapçaya tercüme edilen Yunan felsefesi eserleri gibi Avrupa'ya çok büyük katkıları olan önemli eserler bulunmaktadir.

94 Watt, İslam Avrupa'da, s. 142.

95 W. Montgomery Watt, İslam'ın Ortaçağ Avrupası Üzerindeki Etkisi, çev. Ümit Hüsrev Yolsal, Ankara, 2013, s. 111.

96 Koningsveld, The Apology of al-Kindi, Religious polemics in context: papers presented to the second international conference of the Ladien institute for the study of religions, s. 4-5.

97 12. Yüzyıl Rönesans'ı ifadesi Amerikalı bilgin Charles Homer Haskin'in yazdığ1 kitabıyla yaygın kullanım kazanmıştır. (Bkz. Charles Homer Haskins, The Renaissance of the Twelfth Century, Harvard, 1971) 
Toledo Koleksiyonu: Sebepleri ve Sonuçlarıyla İlk Oryantalist Çalışmalar

ii. Toledo merkezli olup, İspanya'da yapılan Arapçadan Latinceye tercümeler takriben IX. asırda başlayıp XIII. asırda sona ermiştir. Ayrıca Avrupa'ya Müslümanların ilminin yayılmasının başka bir yolu da Yahudilerin yaptığı tercümeler ve Yahudilerin Hıristiyan bilginleriyle olan yakınlıkları sayesinde gerçekleşmiştir.

iii. 1202 yılında Pisalı Leonardo Fibonnacci'nin müslüman bir hocadan matematik dersi almış ve Liber abaci eserini yazmıştır. Bu sayede Avrupa Arapça rakamlarının ve onluk sistemin kolaylığını öğrenmiştir. Bu tarihten sonra hesaplarında Roma rakamlarını bırakmışlar; böylece astronomide yeni rakamlarla kolayca işlem yapıp bu alanda yapılan çalışmaların önü açılmıştır. Hatta bazı araştırmacılar Avrupa'nın Yunandan daha çok İslam'ın tesiri altında kaldığını net bir şekilde ortaya koymuştur. Avrupa tercüme faaliyetleri sırasında elde ettiği bilgi birikimi ve entelektüel hayatlarına eklenenlerle ilk Rönesansını yaşamış ve sonrasında anılacak olan Rönesansın temelleri atılmıştır.

iv. Hıristiyanların Müslümanlarla ilgili bilgileri şifâhilikten kitâbîliğe geçmiştir.

v. İslam düşünce hayatı tercümeler yoluyla Avrupa düşüncesine malzeme sağlamıştır.

vi. Rönesans'in tetikleyici unsuru olmuştur.

vii. 12. yüzyılda küçük bir âlim grubunun başlattığı bu hareket 500 yıldan fazla bir zaman boyunca Avrupalı Hiristiyanların İslam'ı anlamalarında belirleyici etkisi olmuştur.

viii. Avrupa Tercüme faaliyetleriyle İslam kültürünü ve ticaretini de öğrenmiştir. Bunların arasında özellikle 751'de Semerkand'a ulaşıp Müslümanlara geçen kâğıt yapma tekniğinin tercüme faaliyetleri sayesinde Avrupa'ya aktarıldığı söylenebilir.

ix. Matematikte yapılan tercümelerle Avrupa ilk defa sıfır ve onluk sistemi öğrenmiştir.

x. İlk dönemde başlayan tercümeler Avrupa'da refah ve canlılığın gelişmesini sağlamış; aynı zamanda bu durum Avrupa'nın skolâstik yapısını kökünden sarsmıştır.

xi. Oryantalistik çalışmaların salt bilimsel bir girişim olmaması, beraberinde ötekiyi tanıma ve bir algı yönetimini hedeflemesi 
sebebiyle Avrupa'da XII. yüzyılda başlayıp günümüze kadar gelen muharref İslam imajının oluşmasına yol açmıştır. Bu tercümelerin onlara İslam algısı konusunda sağladığı yegâne yarar, İslam'ı pagan bir din olarak tanımlamaktan vazgeçip, daha önce Yuhanna ed-Dımeşki'nin de seslendirdiği gibi, heretik (Hıristiyanlıktan sapma) bir din olarak tanımlamaya başlamalarıdir.

xii. İslam'la ilgili oluşturulan algı, Hıristiyanları, Müslümanlara karşı savaştıkları takdirde, zulmete karşı nur için savaştıklarına inanmaya yöneltmiş̧ir. Ancak Freud'un yorumuna katılan Watt'a göre; kişinin düşmanına karşı zulmetinin, kendisinde var olup, itiraf edilmemiş karanlığının gün yüzüne çıkmasından ibaret olduğunu söylemektedir. Dolayısıyla Avrupa'da oluşan İslam algısı, aslında Avrupa'nın kendi tasavvur karakterini yansitmaktadır.

xiii. Peter the Venerable tarafından Kur'an ve Apoloji toplanıp Corpus Cluniacense adıyla tek cilt haline dönüştürülmüştür. Haçlı seferlerinde başarısızlıkları arttığında bu koleksiyon onlara İslam'a karşı askersiz manevi/ruhsal bir haçlı seferi düzenlemelerine imkân vermiştir.

Müslümanlar halife $\mathrm{Me}^{\prime}$ mun döneminde yaptığı tercümelerle Aristo'nun De Anima eseri gibi eserleri kendi kültürüne katmayı başarmışken, Avrupa kendi kültürüne sahip çıkmayıp orijinallerinin yok olmasına izin vermiş̧ir. Batı bu eserlerle Arapçadan yapılan tercümeler sonucunda yeniden buluşmuştur. Daha sonra da özellikle Aristo'nun şarihi olan İbn Rüşd'ün eserlerinin tercümesiyle oluşan akım, bugünkü Batı medeniyetinin oluşmasına olumlu yönde katkı sağlamıştır.

\section{Kaynakça}

Abay, Sabire, Müslümanlarla Hıristiyanlar Arasındaki Teolojik İlişkilerin İlk Döneminde Abdülmesih El-Kindi'nin Abdullah b. İsmail El-Haşimi'ye Reddiyesi Örneği, Basılmamış Yüksek Lisans Tezi, Ankara, 2002.

Al-Fārābī, De syllogismo. Incipit TK (TK: L. Thorndike ve P. Kibre, A Catalogue of Incipits of

Mediaeval Scientific Writings in Latin, Cambridge, Mass., 1963.

al-Kindi, Abd al-Mesih b. Ishak, "The Apology of Al-Kindi", ed. Anton Tien, The Early Christian-Muslim Dialogue, A Collection of Documents from The First Three Centruies (632-900) ed. N. A. Newman, Pennsylvania, 1993. 
Toledo Koleksiyonu: Sebepleri ve Sonuçlarıyla İlk Oryantalist Çalışmalar al-Azmeh, Aziz, İslâmlar ve Moderniteler, çev. Elçin Gen, İletişim Yayınları, İstanbul, 2014.

Bruce Eastwood, "America De essentiis by Hermann of Carinthia; Charles Burnett", Speculum, Medieval Academy of America, c.59, no.4, 1984.

Burman, Thomas E., "Tafsir and Translation: Traditional Arabic Qur'an Exegesis and the Latin Qur'ans of Robert of Ketton and Mark of Toledo", Speculum, c. 73, no. 3, 1998.

Clerval, Hermann le Dalmate, “Compte rendu du Congrés scientifique international des Catholiques, II (1891), 163-69).

Davis, N., The Errors of Mohammedanism Exposed: veya A Dialogue between the Arabian Prophet and a Jew, Malta, 1847.

Dozy, Reinhart, Histoire des Musulmanes d'Espagne, , c. II, Leiden, 1861.

Düzgün, Şaban Ali, “Bir Şiddetin Anatomisi: Müslüman ve Latin Batı Dünyası Arasında Haçlı Seferleri Dönemindeki İlişkiler", Dini Araştırmalar, sayı: 20, 2007.

"Oriental Studies and Conception of Islam During the Crusade Period", International Symposium on Orientalism held in Oran, Cezayir, 1999.

Emile Brehier, Historie de la Philosophie, c. I, Paris, 1928.

Fournet, Pierre Auguste. "Blessed Peter of Montboissier." The Catholic Encyclopedia. Vol. 10. New York: Robert Appleton Company, 1911. 9 Sept. 2014

Gabrieli, Francesco, "The Transmission of Learning and Litterary Influences to Western Europe" The Cambridge History of Islam, II/B, Cambridge, 1970.

Gaudeul, Jean-Marie, EncountersEClashes Islam and Chrsitianity in History, Pontificio Istituto di Studi Arabi e Islamici, Roma, 1990.

Haskins, Charles Homer, The Renaissance of Twelfth Century, Harvard University Pres, 1979.

http://faculty.washington.edu/petersen/alfonso/esctra12.htm.

Irwin, Robert, Oryantalistler ve Düşmanları, çev. Bahar Tırnakçı, YK Yayınları, İstanbul, 2008.

Isidoro de las Cagigas, Los Mozarabes, Madrid 1947.

İbn Mâce, Ebu Abdullah Muhammed b. Yezid el-Kazvini, Sunnenu İbn Mâce, Daru'l- İhyâi'l-Kütübi'l-Arabiyye, 1953.

Karlığa, Bekir, İslam Düşüncesinin Batı Düşüncesine Etkileri, İstanbul, 2004.

Kirsch, J. P., s.v. "Archdeacon", Thr Catholic Encylopedia, c. I, New York, 1907.

Koningsveld, P.S. van, The Apology of al-Kindi, Religious polemics in context: papers presented to the

second international conference of the Leiden institute for the study of religions, ed: Tl.Hettema \& A van der Kooiji, Leiden, 2000. 
Kritzeck, James, Peter the Venerable and Islam, Princeton University Press, Princeton, New Jersey, 1964.

Mazhar, Celâl, Eseru'l-íslam fi'l-Komedya'l-ílahiyye, Kahire, 1980

Mingana, A., An Ancient Syriac Translations of the Qur'an Exhibiting New Verses and Variants, Bulletin of the John Rylands Library, Manchester, c. IX, 1925.

Özdemir, Mehmet, "İslam Tarihinde Doğululaşma ve Batılılaşma Tartışmaları: Tuleytula Örneği", İslamiyat, cilt: 7, sayı 3, 2004. Metin, “İbn Rüşd'ün Aristo'nun Topikleri, Retoriki, Poetiki üzerine üç kısa şerhi”, KADER, 7/2, 2009.

Palacios, Miguel Asin, La Escatologia Musulmana en la Divina Comedia, Madrid, 1961.

Pijper, G. F., Het boek der duizend vragen, Leiden, 1924.

Pym, Anthony, Tranaltio, disputatio, and the first Latin Qur'an, y.y., 1995-96.

Sendino, Jose Munoz, La Escala de Mahoma, Madrid, 1949.

Tartar, G., Dialogue Islamo-Chrétien sous le Calife Al-Ma'mûn (813-834), Les Epitres d'Al-Hâshimî et d'Al-Kindî̀, Strassbourg, 1977.

Thorndike, Lynn, "John of Seville”, Speculum, c.34, no:1, 1959.

Tolan, John Victor, Saracens: Islam in The Medivial Europien Imagination, Columbia University Press, 2002.

Türkiye Diyanet Vakfı İslam Ansiklopedisi, c. 32, İstanbul, 2006.

Van Riett, Simone, Avicenna Latinus, Liber de Anima, 1994.

Verbeke, G., Introduction sur la Doctrine Psychologique d'Avicenne, Brill, Leiden, 1968.

Watt, Montgomary, İslam Avrupa'da, çev. Hulusi Yavuz, İfav Yayınları, İstanbul, 2000.

İslam'ın Ortaçă̆ Avrupası Üzerindeki Etkisi, çev. Ümit Hüsrev Yolsal, Ankara, 2013.

Yazıcı, Mustafa, Haçlı Savaşları Döneminde Müslümanlar ve Hıristiyanlar Arasındaki Teolojik İlişkiler: Toledo Okulu Örneği, Basılmamış Yüksek Lisans Tezi, Ankara, 2003.

Ziya Paşa, Endülüs Tarihi, Sesli Kitaplar, İstanbul, 2004. 


\section{Mílel VE NiHAL}

inanç, kültür ve mitoloji araştırmaları dergisi

Cilt/Volume: 12 Sayı/Number: 1 Ocak - Haziran / January - June 2015

ISSN: 1304-5482

Bu dergi uluslararası EBSCO HOST Research Databases veri indeksi ve

TÜBİTAK-ULAKBİM Sosyal ve Beşeri Bilimler Veri Tabanı tarafından taranmaktadır.

\section{Sahibi / Owner}

Milel ve Nihal Eğitim, Kültür ve Düşünce Platformu Derneği adına Şinasi Gündüz

$$
\begin{gathered}
\text { Yazı İşleri Sorumlusu / Legal Representative } \\
\text { Yasin Aktay }
\end{gathered}
$$

Editör / Editor

Şinasi Gündüz

Editör Yrd. / Co-Editor

Cengiz Batuk

Hakan Olgun

\section{Sayı Editörü / Editor of Issue}

Feridun Bilgin

Yayın Kurulu/ Editorial Board*

Alpaslan Açıkgenç, Ayaz Akkoyun, Yasin Aktay, Mahmut Aydın,

Cengiz Batuk, Şinasi Gündüz, İbrahim Kayan, Hakan Olgun, Necdet Subaşı, Burhanettin Tatar

\section{Danışma Kurulu/Advisory Board*}

Baki Adam (Prof. Dr., AÜ); Mohd. Mumtaz Ali (Prof. International Islamic U. Malezya); Adnan Aslan (Prof.Dr., Süleyman Şah Ü.); Kemal Ataman (Doç.Dr., Uludağ Ü.); Mehmet Akif Aydın (Prof. Dr., Marmara Ü.); Yılmaz Can (Prof. Dr., OMÜ); Ahmet Çakır (Doç. Dr., OMÜ); Mehmet Çelik

(Prof. Dr., Celal Bayar Ü.); Waleck S. Dalpour (Prof. University of Maine at Farmington); İsmail

Engin (Dr., Berlin); Cemalettin Erdemci (Prof.Dr. YYÜ); Tahsin Görgün (Prof.Dr., 29

Mayıs Ü.) Ahmet Güç (Prof.Dr., Uludağ Ü.); Recep Gün (Doç. Dr., OMÜ); Ö. Faruk Harman

(Prof.Dr., Mar.Ü.); Erica C.D. Hunter (Dr., Cambridge U.); Mehmet Katar (Prof. Dr., A.Ü.);

Mahmut Kaya (Prof. Dr., İ.Ü.); Sadık Kılıç (Prof.Dr., Atatürk Ü..); Şevket Kotan (Y.Doç.Dr., İ.Ü.);

İlhan Kutluer (Prof.Dr., Mar. Ü.); George F. McLean (Prof. Catholic Univ., Washington DC); Ahmet Yaşar Ocak (Prof. Dr., Hacettepe Ü.); Jon Oplinger (Prof. University of Maine at Farmington); Ömer

Özsoy (Prof.Dr., Frankfurt U.); Roselie Helena de Souza Pereira (Mestre em

Filofia-USP; UNICAMP Brasil); Ekrem Sarıkçığlu (Prof.Dr., SDÜ); Hüseyin Sarıoğlu (Prof.Dr.,

IÜ); Bobby S. Sayyid (Dr. Leeds U.); Mustafa Sinanoğlu (Prof.Dr., 29 Mayıs Ü.); Mahfuz Söylemez

(Prof.Dr. İÜ); Necdet Subaşı (Y.Doç.Dr., DİB); Bülent Şenay (Prof.Dr., UÜ); İsmail Taşpınar

(Prof.Dr. Mar.Ü.); C. Sadık Yaran (Prof.Dr., OMÜ); Ali Murat Yel (Prof.Dr., Fatih Ü.); Hüseyin Yılmaz (Doç.Dr., YYÜ); Ali İhsan Yitik (Prof. Dr., DEÜ)

$$
\text { * Soyadına göre alfabetik sıra / In alphabetical order }
$$

\section{Kapak ve Sayfa Tasarımı / Cover \& Page Design} İnan $\mathrm{Avc1}$

\section{Baskı / Publication}

Ladin Ofset - İstanbul, Ekim 2015

2.Mat. Sit. 3 NB 15 Topkapi İstanbul / İsmail Tüz 02125012418

Yönetim Yeri / Administration Place

Milel ve Nihal Eğitim, Kültür ve Düşünce Platformu Derneği

Fevzipaşa Cad. Şehit Mehmet Sarper Alus Sok. No: 5, K.: 3, Tel: (0212) 5339731 Fatih/İstanbul www.milelvenihal.org e-posta: dergi@milelvenihal.org

Milel ve Nihal yılda iki sayı olarak altı ayda bir yayımlanan uluslararası hakemli bir dergidir.

Milel ve Nihal' de yayımlanan yazıların bilimsel ve hukuki sorumluluğu yazarlarına aittir. Yayım dili Türkçe ve İngilizce' dir. Yayımlanan yazıların bütün yayın hakları Milel ve Nihal'e ait olup, yayıncının izni olmadan kısmen veya tamamen basılamaz, çoğaltılamaz ve elektronik ortama taşınamaz. Yazıların yayımlanıp yayımlanmamasından yayın kurulu sorumludur. 


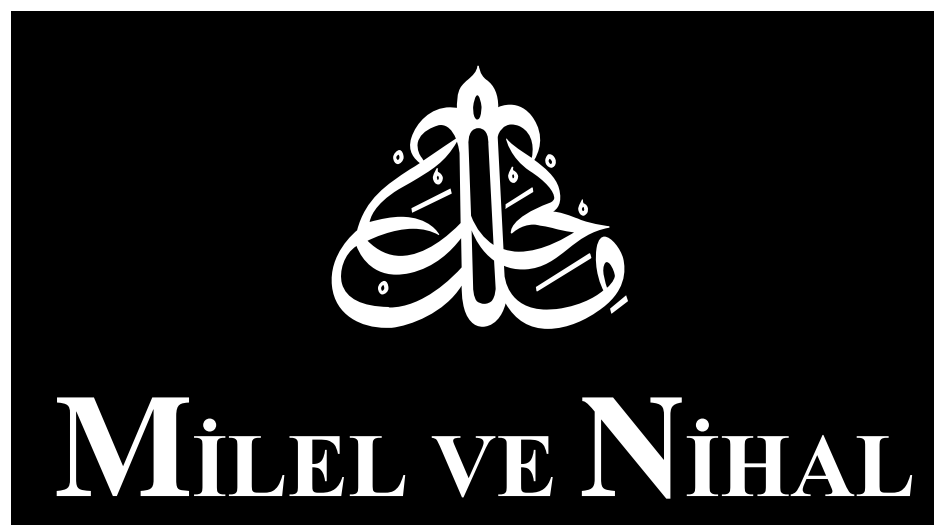

inanç, kültür ve mitoloji araştırmaları derogisi

ISSN: 1304-5482

ENDÜLÜS

Cilt/Volume: 12 Sayı/Number: 1

Ocak - Haziran / J anuary - June 2015 
